\title{
LAYANAN PENDIDIKAN AGAMA SESUAI AGAMA SISWA DI SEKOLAH
}

\section{RELIGIOUS EDUCATION SERVICE ACCORDING TO STUDENT'S RELIGION AT SCHOOLS}

\author{
Hayadin \\ Pusat Penelitian Pendidikan Agama dan Keagamaan \\ Balitbang \& Diklat Kemenag RI. \\ Jl. M.H. Thamrin, nomor 6. Lantai 19. Jakarta Pusat. \\ Email: hayadin006@gmail.com
}

Naskah diterima 9 Februari 2017, direvisi 15 Maret 2017, disetujui 12 April 2017

\begin{abstract}
This study aims at determining best practices for religious education at schools. Because it is widely reported by media that discrimination against religious education at schools occurred where minority religious students do not receive religious education services in accordance with their religion and are not taught by teachers with the same religion. This study finds facts that minority religious students get appropriate religious teaching services and by religious teachers in accordance with the religion of the students. The case is found at: Labschool High School Jakarta, Catholic Santo Joseph High School Denpasar, Ananda High School Bekasi, SLUA High School Denpasar, Gloria Vocational High School Manado, State Junior High School 2 Ende Flores, State Junior High School 1 Ambon, State High School 1 Denpasar, State High School 1 Bogor, State High School 1 Manado, Vocational High School Singkawang and Vocational High School Bangkabelitung. The study method used a qualitative approach in 2015 at the schools mentioned above. The sources of data came from documents, observation and interview of informants such as school leaders, religious teachers and students. In addition to the interview, focus group discussion was also conducted. The study concludes that all students receive religious education services in accordance with their religion and are taught by religious teachers with the same religion as those of the students. The religious teacher is appointed, either by the government, local government or principal with the approval of the school committee, or by the foundation.
\end{abstract}

Keywords: Religious Education, Student, School

\begin{abstract}
Abstrak
Penelitian ini bertujuan untuk mengetahui praktek terbaik bagi pendidikan agama di sekolah. Karena banyak diberitakan oleh media bahwa pendidikan agama di sekolah terjadi diskriminasi dimana siswa yang beragama minoritas tidak mendapatkan layanan pendidikan agama sesuai agama yang dianutnya dan tidak diajarkan oleh guru yang seagama. Penelitian ini menemukan fakta dimana para siswa yang beragama minoritas, mendapatkan layanan pengajaran agama yang sesuai dan oleh guru agama yang sesuai agama siswa. Kasus tersebut dijumpai pada: SMA Labschool Jakarta, SMA Katholik Santo Joseph Denpasar, SMA Ananda Bekasi, SMA SLUA Denpasar, SMK Gloria Manado, SMPN 2 Ende Flores, SMPN 1 Ambon, SMAN 1 Denpasar, SMAN 1 Bogor, SMAN 1 Manado, SMK Singkawang, and SMK Bangkabelitung. Metode penelitian menggunakan pendekatan kualitatif pada tahun 2015 pada sekolah tersebut di atas. Sumber data berasal dari dokumen, observasi, dan wawancara para informan seperti pimpinan sekolah, guru agama, dan siswa. Selain wawancara juga dilakukan fokus grup diskusi. Penelitian menyimpulkan bahwa seluruh siswa memperoleh layanan pendidikan agama sesuai agama yang dianutnya, dan diajarkan oleh guru agama yang seagama dengan siswa. Guru agama tersebut diangkat, baik oleh pemerintah, pemerintah daerah, kepala sekolah dengan persetujuan komite sekolah, atau oleh yayasan.
\end{abstract}

Kata Kunci: Pendidikan Agama, Siswa, Sekolah 


\section{PENDAHULUAN}

Dalam undang-undang sistem pendidikan nasional dinyatakan tentang pentingnya layanan pendidikan agama bagi siswa, dan harus dilaksanakan oleh guru yang seagama dengan siswa. Secara detil dinyatakan sebagai berikut: "Setiap peserta didik pada setiap satuan pendidikan berhak mendapatkan pendidikan agama sesuai dengan agama yang dianutnya dan diajarkan oleh pendidik yang seagama"1. Aturan tersebut menjadi landasan yuridis sekaligus filosofis penyelenggaraan pendidikan agama, khususnya yang diselenggarakan di sekolah publik. Sekolah publik yang diselenggarakan dalam rangka memenuhi sistem pendidikan nasional, menjadi instrumen negara dalam rangka mencapai tujuan pembangunan bangsa, bahkan tujuan bernegara, yakni masyarakat yang sejahtera, cerdas, adil dan makmur berdasarkan nilai-nilai ketuhanan, kemanusiaan, nasionalisme, demokrasi, dan keadilan sosial.

Dalam hal layanan pendidikan agama di sekolah, selama ini terjadi banyak kasus pengabaian pendidikan agama sesuai agama siswa di sekolah. Sebagai contoh, pada tahun 2013 Puslitbang PENDA mendalami dan mengkaji kasus penolakan sejumlah lembaga pendidikan Katholik di kota Blitar, Jawa Timur, untuk memberikan layanan pelajaran agama non-Katholik kepada siswa yang beragama lain (Islam, Hindu, Buddha, dan Konghucu).Ada enam sekolah Katholik yang menerapkan kebijakan tersebut, antara lain SD Katolik Santa Maria, SD Katolik Yos Sudarso, SMP Katolik Yos Sudarso,

${ }^{1}$ UU nomor 20 tahun 2003, Sistem Pendidikan Nasional.Pasal 12; ayat, poin a.
SMP Katolik Yohanes Gabriel, SMU Katolik Diponegoro, dan SMK Katolik Santo Yosep².

Penelitian lain yang dilakukan oleh Balai Litbang Agama Makassar, menemukan bahwa layanan pendidikan agama di sekolah-sekolah yayasan atau organisasi keagamaan, hanya memberikan layanan pendidikan agama yang menjadi ciri khas yayasan. Mereka antara lain: SMA Pembangunan V, Yayasan Pendidikan Islam Waena; SMA Yayasan Pendidikan Kristen Diaspora, SMA Kristen Yayasan Pendidikan Kristen Makale, SMA Yayasan Pendidikan Kristen Manado, SMP Frater Makassar, SMA Katolik Yos Sudarso Balikpapan. Meskipun pelaksanaan pendidikan agama pada sekolah tersebut tidak sampai pada ritual dan tujuan konversi agama, sekolah tersebut lalai untuk memenuhi hak anak dalam menjalankan ibadah sesuai agama dan keyakinannya ${ }^{3}$.

Selain kasus di atas, di media online ditemukan pula informasi tentang adanya diskriminasi dalam pembelajaran pendidikan agama di sekolah. Di salah satu pojok kompas on-line (kompasiana) misalnya, terdapat keluhan seorang siswa yang merasa diperlakukan tidak adil pada salah satu sekolah negeri tempat ia belajar. Ia menyatakan bahwa tidak semestinya sekolah negeri yang menjadi milik publik hanya mengajarkan agama siswa yang mayoritas ${ }^{4}$. Artinya, ada praktek di sekolah kalau siswa yang beragama yang jumlahnya sedikit,

${ }^{2}$ Puslitbang Pendidikan Agama dan Keagamaan, (2012): Laporan Tahunan Pendidikan Agama dan Keagamaan di Indonesia tahun 2013. Jakarta, p. 15.

${ }^{3}$ Laporan Penelitian Balai Litbang Agama Makasar. (2014): Layanan Pendidikan Agama pada Ormas Keagamaan, Makassar.

${ }^{4}$ http://sosbud.kompasiana.com/2013/07/12/ menjadi-minoritas-di-sekolah-negeri-576236.html, dikutip pada tanggal: 15 Januari 2015. 
tidak mendapatkan layanan pendidikan agama.Munculnya berita tentang sekolah intoleran, menjadi salah satu indikasi tentang layanan pendidikan agama terhadap siswa yang masih diskriminatif di sekolah ${ }^{5}$.

Meskipun demikian, kita menemukan beberapa kasus yang dapat dijadikan sebagai contoh dan pelajaran (lesson learn) dalam membangun iklim pendidikan yang toleran dan damai. Beberapa contoh dari implementasi aturan tersebut misalnya:SMA Muhammadiyah Kupang yang menyediakan layanan pendidikan agama Kristen kepada siswa Kristen, dan pendidikan agama Katholik kepada siswa yang beragama Katholik dan diajarkan oleh guru agama yang seagama dengan siswa ${ }^{6}$. Di Semarang Jawa Tengah juga ada berita tentang Sekolah Dasar Karang Turi yang mayoritas siswa dan warga sekolahnya beragama Kristen, memfasilitasi penyelenggaraan pesantren kilat kepada siswanya yang muslim di sekolah tersebut ${ }^{7}$.

Fakta dan informasi seperti tersebut di atas, merupakan contoh teladan yang semestinya diikuti oleh lembaga pendidikan lainnya di Indonesia dalam rangka membangun iklim pendidikan yang toleran, damai, dan berkualitas tanpa diskriminatif. Oleh karena itu, upaya

${ }^{5} \mathrm{http://www.solopos.com/2015/01/04/}$ sekolah-intoleran-masih-muncul-diindonesia-564975, dikutip pada tanggal: 13 Januari 2015.

${ }^{6}$ Imam Tholkhah. 2013. Pendidikan Toleransi Keagamaan: Studi Kasus SMA Muhammadiyah Kupan Nusa Tenggara Timur, Jurnal Edukasi Vol. 11, nomor 2, pp. $165-181$.

${ }^{7}$ http://www.sesawi.net/2012/08/14/meskisiswa-muslim-minim-sd-karangturi-semaranggelar-kegiatan-ramadhan/, dikutip pada tanggal 13 Januari 2015. mengkaji kasus ini secara komprehensif dan menyebarluaskannya dalam bentuk laporan akademis menjadi hal yang penting. Ini menjadi ikhtiar yang bersifat persuasif dan arif untuk menunjukkan contoh teladan untuk hidup bersama, dalam bangsa dan bernegara yang multikultur. Diharapkan dengan pelajaran dan contoh teladan yang diangkat dari kegiatan riset akan lambatlaun (atau secepatnya) tumbuh semangat bersama dalam memelihara semangat hidup bersama yang rukun dan saling menghormati.

Berdasarkan latarbelakang seperti terurai di atas, terlihat spektrum permasalahan yang sangat luas tentang layanan pendidikan agama sesuai agama siswa di sekolah. Beberapa pertanyaan yang dapat dikemukakan, antara lain: sikap dan wawasan penyelenggara pendidikan, baik pemilik yayasan, atau birokrat yang memimpin lembaga pendidikan milik pemerintah; bagaimana ketersediaan guru agama di sekolah, bagaimana sistem rekruitmen, pembinaan karier, penggajian, insentif dan penghargaan terhadap guru agama di sekolah; bagaimana pola dan bentuk penyusunan, implementasi, kurikulum pendidikan agama di sekolah; perencanaan, pelaksanaan dan evaluasi pembelajaran pendidikan agama di sekolah; tempat dan alokasi waktu pembelajaran pendidikan agama; bagaimana pengadaan sarana dan fasilitas serta sumber belajar pendidikan agama di sekolah; bagaimana interaksi sosial antar siswa dan warga sekolah, iklim pembelajaran, dan aktivitas kesiswaan yang bernuansa religius di selenggarakan di sekolah; Faktor-faktor apa saja yang menjadi pendukung dan penghambat 
kegiatan pembelajaran pendidikan agama sesuai agama siswa di sekolah.

Dari berbagai pertanyaan tersebut, rumusan masalah dalam penelitian ini dibatasi sebagai berikut: "Bagaimana layanan pembelajaran pendidikan agama sesuai agama yang dianut oleh siswa pada beberapa Sekolah Menengah Atas (SMA) di Indonesia"?Tujuan penelitian adalah untuk "mengetahui layanan pembelajaran pendidikan agama sesuai agama yang dianut oleh siswa pada beberapa Sekolah Menengah Atas (SMA) di Indonesia"

Penelitian ini diharapkan memberi manfaat kepada seluruh stakeholders pendidikan khususnya masyarakat dan lembaga penyelenggara pendidikan. Melalui penelitian ini publik menemukan kasus yang dapat diteladani sebagai lesson learn tentang penyelenggaraan pendidikan dengan memenuhi layanan agama sesuai agama anak. Ulasan ini diharapkan dapat membangun optimisme pemerintah dan pengamat serta pemerhati pendidikan agama tentang upaya memposisikan sekolah sebagai ujung tombak membangun budaya toleransi dan multikulturalisme dalam kehidupan berbangsa dan bernegara.

\section{Landasan Konseptual}

Beberapa konsep yang relevan untuk di kaji dalam rangka penelitian ini antara lain adalah: hak asasi beragama, kebebasan beragama dalam konstitusi Indonesia, serta eksistensi sekolah sebagai lembaga publik dan proses belajar mengajar di sekolah. Berikut di bawah ini akan dijelaskan konsep tersebut.

\section{Hak Asasi Manusia Untuk Beragama}

Kebebasan beragama merupakan salah satu hak dasar yang melekat pada setiap orang. Dalam deklarasi universal tentang hak asasi manusia (HAM) yang diadopsi Perserikatan Bangsa-Bangsa (PBB) tahun 1948, disebutkan mengenai pokok-pokok kebebasan beragama itu. Pasal 18 misalnya menyatakan bahwa setiap orang mempunyai hak kebebasan berpikir, berkesadaran, dan beragama, termasuk kebebasan memilih dan memeluk agama, dan menyatakan agamanya itu dalam pengajaran, pengamalan, dan beribadatnya, baik secara sendiri-sendiri mauoun dalam kelompok. Dalam kovenan internasional tentang hakhak sipil dan politik yang disahkan PBB pada tanggal 16 Desember 1966, pada pasal 18 juga dinyatakan hal yang sama dengan apa yang disebutkan dalam pasal 18 deklarasi universal tentang HAM PBB tersebut. ${ }^{8}$

Kemudian dalam Kovenan Internasional tentang hak-hak ekonomi, sosial, dan budaya yang disyahkan PBB tanggal 16 Desember 1966, pada pasal 13 dinyatakan bahwa semua negara pihak yang meratifikasi kovenan itu harus menghormati kebebasan orang tua atau wali untuk menjamin bahwa pendidikan anak mereka di sekolah-sekolah dilakukan sesuai dengan agama mereka. ${ }^{9}$

Pemerintah Indonesia telah meratifikasi Kovenan Internasional tentang hak sipil dan politik lewat UU No. 12 tahun 2005, tentang Pengesahann Kovenan Internasional tentang hak-hak sipil dan Politik. Itu

${ }^{8}$ Prof. Atho Mudzhar. (2010). Pengaturan Kebebasan Beragama dan Penodaan Agama di Indonesia dan Berbagai Negara. Makalah pada Kajian tentang Putusan Mahkamah Konstitusi No. 140 tanggal 19 April, tentang Uji Materil UU No. 1/PNPS/1965, p. 1.

${ }^{9} \mathrm{Ibid}$. 
berarti bahwa ketentuan dalam deklarasi universal tersebut diakui dan berlaku secara mengikat di wilayah negara kesatuan Republik Indonesia (NKRI). Berdasarkan kovenan tersebut, inti normatif dari hak kebebasan beragama atau berkepercayaan dapat dirumuskan dalam 8 elemen: 1). Kebebasan internal: setiap orang berhak atas kebebasan berfikir, berkepercayaan dan beragama; hak ini mencakup kebebasan untuk setiap orang menganut, menetapkan, merpertahankan atau pindah agama atau kepercayaan. 2). Kebebasan eksternal: setiap orang mempunyai kebebasan, baik sendiri atau bersama-sama dengan orang lain, di tempat umum atau tertutup, untuk menjalankan agama atau kerpercayaannya dalam kegiatan pengajaran, pengamalan, ibadah dan pentaatan. 3). Tanpa dipaksa: tidak seorang pun dapat dipaksa sehingga terganggu kebebasannya untuk menganut atau menetapkan agama atau kepercayaannya sesuai dengan pilihannya. 4). Tanpa diskriminasi: Negara berkewajiban untuk menghormati dan menjamin hak kebebasan beragama atau berkepercayaan bagi semua orang yang berada dalam wilayahnya dan tunduk pada wilayah hukumnya, hak kebebasan beragama atau berkepercayaan tanpa pembedaan apa pun seperti ras, warna kulit, jenis kelamin, bahasa, agama, politik atau pendapat lain, kebangsaan atau asal-usul lainnya, kekayaan, kelahiran atau status lainnya. 5). Hak orang tua dan wali: Negara berkewajiban untuk menghormati kebebasan orang tua dan apabila diakui, wali hukum yang sah, untuk memastikan bahwa pendidikan agama dan moral bagi anak-anak mereka dilakukan sesuai dengan kepercayaan mereka sendiri, dibatasi oleh kewajiban melindungi hak kebebasan beragama atau berkepercayaan setiap anak sesuai dengan kemampuan anak yang sedang berkembang. 6). Kebebasan korporat dan kedudukan hukum: komunitas keagamaan boleh mempunyai kedudukan hukum dan hak kelembagaan untuk mewakili hak dan kepentingannya sebagai komunitas. 7). Pembatasan yang diperbolehkan terhadap kebebasan eksternal: kebebasan menjalankan agama atau kepercayaan seseorang hanya dapat dibatasi oleh ketentuan berdasarkan hukum, dan pembatasan tersebut diperlukan untuk melindungi: keamanan, ketertiban, kesehatan, nilai moral masyarakat, atau hak-hak mendasar orang lain. 8). Tidak boleh dikurangi: Negara tidak boleh mengurangi hak kebebasan beragama atau berkepercayaan, bahkan dalam keadaan darurat. ${ }^{10}$

Diskriminasi adalah setiap pembatasan, pelecehan, atau pengucilan yang langsung ataupun tak langsung didasarkan pada pembedaan manusia atas dasar agama, suku, ras, etnik, kelompok, golongan, status sosial, status ekonomi, jenis kelamin, bahasa, keyakinan politik, yang berakibat pengurangan, penyimpangan atau penghapusan pengakuan, pelaksanaan atau penggunaan hak asasi manusia dan kebebasan dasar dalam kehidupan baik individual maupun kolektif dalam bidang politik, ekonomi, hukum, sosial, budaya, dan aspek kehidupan lainnya. ${ }^{11}$ Setiap orang

${ }^{10}$ Nicola Colbran. 2007. Hak Kebebasan Beragama atau Berkepercayaan, Makalah Workshop Memperkuat Justisiabilitas Hak-hak Ekonomi, Sosial, dan Budaya: Prospek dan Tantangan, Yogyakarta, 13 November, p. 2.

${ }^{11}$ Undang Undang Republik Indonesia nomor 39 tahun 1999, tentang Hak Asasi Manusia, pasal 1, ayat 3. 
bebas memeluk agamanya masing-masing dan untuk beribadat menurut agamanya dan kepercayaannya itu. ${ }^{12}$ Negara menjamin kemerdekaan setiap orang memeluk agamanya dan kepercayaannya itu. ${ }^{13}$

Dalam kaitan dengan posisi anak yang belumdewasa,kovenanInternasionaltentang Hak-Hak Anak yang diadopsi PBB tanggal 30 November 1989, dinyatakan bahwa negaranegara yang telah meratifikasi kovenan itu, harus menghormati hak agama anak. ${ }^{14}$ Selanjutnya ketentuan tersebut diperkuat melalui undang-undang Perlindungan Anak Nomor 23 Tahun 2002, yang menyatakan: (1) Setiap anak mendapat perlindungan untuk beribadah menurut agamanya.; (2) Sebelum anak dapat menentukan pilihannya, agama yang dipeluk anak mengikuti agama orang tuanya. ${ }^{15}$ Negara, pemerintah, masyarakat, keluarga, orang tua, wali, dan lembaga sosial menjamin perlindungan anak dalam memeluk agamanya. Perlindungan tersebut meliputi pembinaan, pembimbingan, dan pengamalan ajaran agama bagi anak. ${ }^{16}$

Setiap orang yang dengan sengaja menggunakan tipu muslihat, rangkaian kebohongan, atau membujuk anak untuk memilih agama lain bukan atas kemauannya sendiri, padahal diketahui atau patut diduga bahwa anak tersebut belum berakal dan belum bertanggung jawab sesuai dengan agama yang dianutnya dipidana dengan pidana penjara paling lama 5 (lima)

${ }^{12}$ Ibid., pasal 22, ayat 1 .

${ }^{13}$ Ibid., pasal 22, ayat 2.

${ }^{14}$ Prof. Atho Mudzhar, Pengaturan Kebebasan Beragama..., op. cit., p. 2.

${ }^{15}$ UU nomor 23 tahun 2002 tentang Perlindungan Anak, pasal 42.

${ }^{16}$ Ibid., pasal 43. tahun dan/atau denda paling banyak $\mathrm{Rp}$ 100.000.000,00 (seratus juta rupiah). ${ }^{17}$

Dalam konstitusi Indonesia juga dinyatakan bahwa "Negara menjamin kemerdekaan tiap-tiap penduduk untuk memeluk agamanya masing-masing dan untuk beribadat menurut agamanya dan kepercayaannya itu"18. Rumusan tersebut kemudian disempurnakan dalam naskah amandemen kedua UUD-45, yakni: "Setiap orang bebas memeluk agama dan beribadat menurut agamanya, memilih pendidikan dan pengajaran, memilih pekerjaan, memilih kewarganegaraan, memilih tempat tinggal di wilayah negara dan meninggalkannya, serta berhak kembali. ${ }^{19}$ Setiap orang berhak atas kebebasan meyakini kepercayaan, menyatakan pikiran dan sikap, sesuai dengan hati nuraninya. ${ }^{20} \mathrm{Hak}$ untuk hidup, hak untuk tidak disiksa, hak kemerdekaan pikiran dan hati nurani, hak beragama, hak untuk tidak diperbudak, hak untuk diakui sebagai pribadi di hadapan hukum, dan hak untuk tidak dituntut atas dasar hukum yang berlaku surut adalah hak asasi manusia yang tidak dapat dikurangi dalam keadaan apa pun. Setiap orang berhak bebas dari perlakuan yang bersifat diskriminatif atas dasar apa pun dan berhak mendapatkan perlindungan terhadap perlakuan yang bersifat diskriminatif itu. ${ }^{21}$ Perlindungan, pemajuan, penegakan, dan pemenuhan hak asasi manusia adalah tanggung jawab negara, terutama pemerintah. ${ }^{22}$ Intinya secara sintesis dapat dinyatakan bahwa

\footnotetext{
${ }^{17}$ Ibid., pasal 86.

${ }^{18}$ UUD 1945, pasal 29, ayat 2.

${ }^{19}$ UUD 1945, Amandemen Ke-2, pasal 28E, ayat 1.

${ }^{20}$ Ibid., ayat 2 .

${ }^{21}$ Ibid.

${ }^{22}$ Ibid., ayat 4.
} 
setiap individu yang sudah dewasa memiliki kebebasan untuk memilih dan menganut kepercayaan tertentu, dan pemerintah harus menjamin hak tersebut.

\section{Eksistensi Sekolah Sebagai Lembaga Publik}

Sekolah adalah sebutan lain dari lembaga pendidikan atau satuan pendidikan. Satuan pendidikan adalah kelompok layanan pendidikan yang menyelenggarakan pendidikan pada jalur formal, nonformal, dan informal pada setiap jenjang dan jenis pendidikan. ${ }^{23}$ Sekolah menurut kamus adalah bangunan atau lembaga untuk belajar dan mengajar serta tempat menerima dan memberi pelajaran, menurut tingkatannyaada dasar, lanjutan, tinggi, menurut jurusannya ada dagang,guru, teknik, pertanian, dsb. ${ }^{24}$ Dalam konteks seperti ini, kita mengenal sekolah dasar dan sekolah menengah pertama untuk jenjang pendidikan dasar, serta sekolah menengah untuk jenjang pendidikan menengah.

Banyak ahli dan praktisi pendidikan dan ekonomi memandang pendidikan sebagai lembaga publik, atau lembaga layanan publik. Salah satu alasannya karena lembaga pendidikan harus melibatkan seluruh pihak, tidak hanya segelintir orang. ${ }^{25}$ Bahkan jika ada pihak yang tidak mampu berkontribusi, pihak tersebut harus tetap mendapatkan

${ }^{23}$ UUnomor 20 tahun 2003, Sistem Pendidikan Nasional, pasal 1, ayat 10.

${ }^{24} \mathrm{http}: / /$ kbbi.web.id/sekolah, dikutip, tanggal 9 April 2015.

${ }^{25}$ Dr. Lori Poloni. 2013. Education: A Public or Privat Goods. http://nau.edu/PPI/_Forms/Education-APublic-or-Private-Good/ layanan pendidikan. ${ }^{26}$ Alasan lainnya adalah seperti dikemukakan oleh Smith, Schools are public goods because of their function as jails. Young boys who are not closely supervised by their parents will tend to form violent gangs; the violence perpetrated by these gangs imposes costs that spill over into every segment of society and the economy (go watch the movie City of God for a demonstration of how this works). By forcing boys into a structured environment for most of the day, public schools keep them off the street, creating huge spillover benefits for third parties. Schools are therefore a public good. Incidentally, this is why your junior high probably felt like a state prison - it was one. ${ }^{27}$

Sejalan dengan konsep diatas, sistem pendidikan Indonesia memantapkan prinsip demokratis, dan keadilan dalam penyelenggaraan pendidikan. Secara detil dinyatakan bahwa "Pendidikan diselenggarakan secara demokratis dan berkeadilan serta tidak diskriminatif dengan menjunjung tinggi hak asasi manusia, nilai keagamaan, nilai kultural, dan kemajemukan bangsa. Pendidikan diselenggarakan sebagai satu kesatuan yang sistemik dengan sistem terbuka dan multimakna. Pendidikan diselenggarakan sebagai suatu proses pembudayaan dan pemberdayaan peserta didik yang berlangsung sepanjang hayat. ${ }^{28}$ Oleh karena itu maka setiap warga

\footnotetext{
${ }^{26}$ Sandy Baum and Michael McPhaursen. 2011. Is Education A Public Good or A Private Good. http:// chronicle.com/blogs/innovations/is-education-apublic-good-or-a-private-good/28329

${ }^{27}$ Noah Smith. 2011. Is Education A Public Good?. http://noahpinionblog.blogspot.com/2011/06/iseducation-public-good.html.

${ }^{28}$ UU nomor 20 tahun 2003, pasal 4, ayat 1-3.
} 
negara mempunyai hak yang sama untuk memperoleh pendidikan yang bermutu. ${ }^{29}$

Fungsi sekolah dalam mengemban misi pendidikan adalah untuk pengembangan ilmu pengetahuan anak, membentuk sikap dan perilaku, serta keterampilan yang sesuai dengan kebutuhan masyarakat. Hilda Taba menyatakan "Schoolsarecreated for thelearner's reproduction of knowledge, attitudes, values, and techniques that have cultural relevancy". ${ }^{30}$ Pengetahuan, Keterampilan, sikap dan nilai positif yang diperoleh melalui lembaga pendidikan akan menjadi modal dasar bagi anak untuk kehidupan pribadi, sosial maupun sebagai warga negara. Anak yang tidak memiliki pengetahuan, keterampilan, dan sikap serta nilai positif akan menjadi masalah sosial dan tanggungan negara. Oleh karena itu sekolah harus memberikan akses yang sama kepada seluruh warganya untuk mendapatkan layanan yang merata. Tidak boleh ada yang diistimewakan atau diperlakukan diskriminatif. Raewyn Connell menyatakan:An education that privileges one child over another is giving the privileged child a corrupted education, even as it gives him or her a social or economic advantage. ${ }^{31}$

Dengan demikian, menjadi jelas posisi sekolah yang harus mengayomi dan melayani seluruh golongan warga belajar. Dalam konstitusi yang mengatus sistem pendidikan nasional Indonesia disebutkan bahwa layanan pendidikan harus dilakukan

\footnotetext{
${ }^{29} \mathrm{Ibid}$., pasal 5 , ayat 1.

${ }^{30} \mathrm{Hilla}$ Taba, Current conception of the Function of The School. http://faculty.fordham.edu/kpking/ classes/uege 5102-pres-and-newmedia/Hilda\%20 Taba-\%20Function\%20of\%20the\%20School.pdf

${ }^{31}$ Stewart Riddle. 2011. Education is a public good, not a private commodity

http://theconversation.com/education-is-apublic-good-not-a-private-commodity-31408
}

tanpa diskriminasi. Pemerintah dan pemerintah daerah wajib memberikan layanan dan kemudahan, serta menjamin terselenggaranya pendidikan yang bermutu bagi setiap warga negara tanpa diskriminasi. $^{32}$

Jika merujuk pada prinsip penyelenggaraan pendidikan yang demokratis dan berkeadilan, sesungguhnya kewajiban tersebut juga menunjuk kepada sekolah publik yang dikelolah oleh masyarakat. Sebagaimana diketahui, di Indonesia,selain pemerintah danpemerintah daerah, masyarakat, baik perorangan ataupun kelompok dapat terlibat, berpartisipasi untuk menyelenggarakan pendidikan.

Peran serta masyarakat dalam pendidikan meliputi peran serta perseorangan, kelompok, keluarga, organisasi profesi, pengusaha, dan organisasi kemasyarakatan dalam penyelenggaraan dan pengendalian mutu pelayanan pendidikan. Masyarakat dapat berperan serta sebagai sumber, pelaksana, dan pengguna hasil pendidikan. ${ }^{33}$ Selain peran tersebut, "masyarakat berhak menyelenggarakan pendidikan berbasis masyarakat pada pendidikan formal dan nonformal sesuai dengan kekhasan agama, lingkungan sosial, dan budaya untuk kepentingan masyarakat". Selain peran tersebut, masyarakat dapat berpartisipasi sebagai anggota dari dewan pendidikan dan komite sekolah, bahkan sebagai pengawas yang aktif memantau kegiatan pendidikan.

Masyarakat berperan dalam peningkatan mutu pelayanan pendidikan

\footnotetext{
${ }^{32}$ UUnomor 20 tahun 2003, op.cit., pasal 11, ayat 1.

${ }^{33} \mathrm{Ibid}$., pasal 54, ayat 1-2.
} 
yangmeliputiperencanaan, pengawasan, dan evaluasi program pendidikan melalui dewan pendidikan dan komite sekolah/madrasah. Dewan pendidikan sebagai lembaga mandiri dibentuk dan berperan dalam peningkatan mutu pelayanan pendidikan dengan memberikan pertimbangan, arahan dan dukungantenaga, sarana dan prasarana,serta pengawasan pendidikan pada tingkat nasional, propinsi, dan kabupaten/kota yang tidak mempunyai hubungan hirarkis. ${ }^{34}$ Komite sekolah / madrasah, sebagai lembaga mandiri, dibentuk dan berperan dalam peningkatan mutu pelayanan dengan memberikan pertimbangan, arahan dan dukungan tenaga, sarana dan prasarana, serta pengawasan pendidikan pada tingkat satuan pendidikan ${ }^{35}$. Dalam konteks tersebut, maka sekolah merupakan instusi yang terbuka, dengan struktur, dan sistem yang dibentuk sedemikian rupa dalam rangka memelihara nilai-nilai luhur masyarakat dan membangun transformasi pada kehidupan yang lebih baik.

\section{Layanan Pendidikan Agama Di Sekolah}

Di sekolah, setiap anak berhak mendapatkan pelajaran baik melalui intrakurikuler, ataupun ekstrakurikuler. Terkait dengan kurikulum sistem pendidikan nasional menyatakan pentingnya memperhatikan aspek strategis seperti nilai-nilai religius-universal, kebudayaan, potensi daerah, potensi individu, minat dan bakat bahkan kepentingan nasional. Pengembangan kurikulum dilakukan dengan mengacu pada standar nasional pendidikan untuk mewujudkan tujuan pendidikan nasional. Kurikulum pada semua jenjang dan jenis pendidikan dikembangkan dengan prinsip diversifikasi sesuai dengan satuan pendidikan, potensi daerah, dan peserta didik. Kurikulum disusun sesuai dengan jenjang pendidikan dalam kerangka Negara Kesatuan Republik Indonesia dengan memperhatikan: peningkatan iman dan takwa; peningkatan akhlak mulia; peningkatan potensi, kecerdasan, dan minat peserta didik; keragaman potensi daerah dan lingkungan; tuntutan pembangunan daerah dan nasional; tuntutan dunia kerja; perkembanganilmupengetahuan, teknologi, dan seni; agama; dinamika perkembangan global; dan persatuan nasional dan nilainilai kebangsaan. ${ }^{36}$

Dalam rumusan tujuan pendidikan nasional seperti termuat dalam sistem pendidikan nasional disebutkan bahwa "Pendidikan nasional berfungsi mengembangkan kemampuan dan membentuk watak serta peradaban bangsa yang bermartabat dalam rangka mencerdaskan kehidupan bangsa, bertujuan untuk berkembangnya potensi peserta didik agar menjadi manusia yang beriman dan bertakwa kepada Tuhan Yang Maha Esa, berakhlak mulia, sehat, berilmu, cakap, kreatif, mandiri, dan menjadi warga negara yang demokratis serta bertanggung jawab." Dan secara terminologis, sistem pendidikan nasional merumuskan pendidikan sebagai usaha sadar dan terencana untuk mewujudkan suasana belajar dan proses pembelajaran agar peserta didik secara aktif mengembangkan potensi dirinya untuk memiliki kekuatan spiritual keagamaan,

\footnotetext{
${ }^{36} \mathrm{Ibid}$., pasal 36 , ayat $1-3$.
}

\footnotetext{
${ }^{34}$ Ibid.,pasal 55, ayat 2.

${ }^{35} \mathrm{Ibid}$.,pasal 55, ayat 3 .
} 
pengendalian diri, kepribadian, kecerdasan, akhlak mulia, ...".37

Sebagai cerminan dari bentuk kehidupan sosial dan budaya masyarakat Indonesia yang religius yang kemudian diadopsi secara konstitusional dalam berbagai produk peraturan perundang-undangan di Indonesia, maka pendidikan agama merupakan salah satu mata pelajaran wajib di sekolah mulai dari jenjang pendidikan dasar hingga perguruan tinggi.$^{38}$ Pendidikan agama dimaksudkan untuk membentuk peserta didik menjadi manusia yang beriman dan bertakwa kepada Tuhan Yang Maha Esa serta berakhlak mulia.

Untuk mencapai tujuan tersebut dibutuhkan serangkaian ikhtiar yang sistematis dan sinergis dari berbagai pihak (orang tua, masyarakat, pemerintah dan sekolah). Masing-masing pihak dapat menunaikan tugasnya sesuai dengan kemampuan dan ruang lingkup kewenangan yang dimiliki. Para orang tua dapat mengajarkan dan mendidik anak-anaknya di rumah, masyarakat dapat menyediakan fasilitas pengamalan ibadah sebagai bentuk pendidikan praktis kepada anak didik. Pemerintah dan pemerintah daerah dituntut untuk menciptakan kebijakan yang kondusif bagi peserta didik dan masyarakat untuk mendalami dan mempelajari agama yang dianutnya.

Dalam konteks pendidikan agama tanpa diskriminasi, setiap peserta didik pada setiap satuan pendidikan berhak mendapatkan pendidikan agama sesuai dengan agama yang dianutnya dan diajarkan oleh pendidik

\footnotetext{
${ }^{37}$ Ibid.,pasal 1 , ayat 1.

${ }^{38} \mathrm{Ibid}$.,pasal 37 , ayat $1-2$.
}

yang seagama ${ }^{39}$ Aturant tersebut diatur lebih detail dalam peraturan pemerintah nomor 55 tahun 2007, tentang Pendidikan Agama dan Keagamaan, yakni: Setiap peserta didik pada satuan pendidikan di semua jalur, jenjang, dan jenis pendidikan berhak mendapat pendidikan agama sesuai agama yang dianutnya dan diajar oleh pendidik yang seagama. Setiap satuan pendidikan menyediakan tempat menyelenggarakan pendidikan agama. Satuan pendidikan yang tidak dapat menyediakan tempat menyelenggarakan pendidikan agama sebagaimana dimaksud pada ayat (3) dapat bekerja sama dengan satuan pendidikan yang setingkat atau penyelenggara pendidikan agama di masyarakat untuk menyelenggarakan pendidikan agama bagi peserta didik ${ }^{40}$.

Untuk mempertegas aturan tersebut, maka Kementerian Agama RI mengeluarkan Keputusan Menteri Agama Nomor 16 Tahun 2010, tentang Pengelolaan Pendidikan Agama pada Sekolah. Di dalamnya secara eksplisit dinyatakan bahwa setiap sekolah berkewajiban menyediakan pelajaran agama kepada siswa, dan diajarkan oleh guru yang seagama dengan siswa. Dalam hal jumlah peserta didik yang seagama dalam satu kelas paling sedikit 15 (lima belas) orang wajib diberikan pendidikan agama kepada peserta didik di kelas.Dalam hal jumlah peserta didik yang seagama dalam satu kelas kurang dari 15 (lima belas) orang, tetapi dengan cara penggabungan beberapa kelas paralel mencapai paling sedikit 15 (lima belas) orang, maka pendidikan agama pada sekolah

\footnotetext{
${ }^{39}$ Ibid.,pasal 12, ayat 1.a.

${ }^{40}$ Peraturan Pemerintah (PP) nomor 55 tahun 2007, Pendidikan Agama dan Keagamaan,pasal 4.
} 
dilaksanakan dengan mengatur jadwal tersendiri yang tidak merugikan siswa untuk mengikuti mata pelajaran lain.Dalam hal jumlah peserta didik yang seagama pada sekolah paling sedikit 15 (lima belas) orang, maka pendidikan agama wajib dilaksanakan di sekolah tersebut.Dalam hal jumlah peserta didikyang seagama pada satu sekolah kurang dari 15 (lima belas) orang, maka pendidikan agama dilaksanakan bekerjasama dengan sekolah lain, atau lembaga keagamaan yang ada di wilayahnya ${ }^{41}$ Dari ketentuan tersebut, maka sesungguhnya layanan pendidikan agama di sekolah dilakukan dengan tetap menghormati hak asasi peserta didik sebagai individu, dalam beragama dan belajar agama.

\section{METODE PENELITIAN}

Penelitian ini menggunakan pendekatan kualitatif dengan metode studi kasus (multikasus). Obyek yang diteliti adalah layanan pendidikan agama sesuai agama siswa di sekolah. Secara konseptual pengertian dari layanan pendidikan agama sesuai agama siswa adalah proses belajar mengajar mata pelajaran pendidikan agama yang diselenggarakan oleh sekolah kepada siswanya sesuai agama yang dianut oleh siswa dan diajarkan oleh guru agama yang seagama dengan agama yang dianut oleh anak.

Lokasi penelitian meliputi: kota Denpasar; kota Manado, Ende NTT, Bogor, Jakarta, Pangkalpinang, Singkawang dan Ambon. Pemilihan lokasi penelitian berdasarkan keberadaan siswa minoritas,

${ }^{41} \mathrm{KMA}$ nomor 16 tahun 2010, Pengelolaan Pendidikan Agama di Sekolah, pasal 3 - 4. yakni: siswa yang beragama selain Hindu di wilayah atau sekolah mayoritas beragama Hindu, baik sekolah berstatus negeri atau swasta dipilih di kota Denpasar; siswa yang beragama selain Buddha di wilayah atau sekolah mayoritas beragama Buddha; siswa yang beragama selain Katholik di wilayah atau sekolah mayoritas beragama Katholik, baik yang berstatus negeri atau swasta dipilih di kota Ende provinsi Nusa Tenggara Timur; siswa yang beragama selain Kristen di wilayah atau sekolah mayoritas beragama Kristen, untuk yang berstatus negeri dan swasta dipilih di kota Manado dan Ambon; dan siswa yang beragama non- Islam di wilayah atau sekolah mayoritas muslim untuk yang berstatus negeri dan swasta dipilih di kota Bogor dan Jakarta.

Secara lengkap lokus penelitian digambarkan sebagai berikut:

Tabel 1. Lokasi dan lokus penelitian

\begin{tabular}{|c|c|c|}
\hline No. & Siswa Minoritas & Lokus \\
\hline 1 & $\begin{array}{l}\text { Minoritas Muslim, } \\
\text { Katholik, Kristen, dan } \\
\text { Buddha, Khonghucu } \\
\text { pada sekolah atau daerah } \\
\text { mayoritas Hindu }\end{array}$ & $\begin{array}{l}\text { SMAN } 1 \\
\text { Denpasar, } \\
\text { SLUA Saraswati } \\
\text { Denpasar. }\end{array}$ \\
\hline 2 & $\begin{array}{l}\text { Minoritas Muslim, } \\
\text { Katholik, Kristen, Hinddu, } \\
\text { Khonghucu pada sekolah } \\
\text { atau daerah mayoritas } \\
\text { Buddha }\end{array}$ & $\begin{array}{l}\text { SMA Ananda } \\
\text { Bekasi, dan } \\
\text { SMK Bakti } \\
\text { Pangkalpinang } \\
\text { SMK } \\
\text { Singkawang. } \\
\end{array}$ \\
\hline 3 & $\begin{array}{l}\text { Minoritas Muslim, } \\
\text { Kristen, Hindu, Buddha, } \\
\text { Khonghucu pada sekolah } \\
\text { atau daerah mayoritas } \\
\text { Katolik }\end{array}$ & $\begin{array}{l}\text { SMPN } 2 \text { Ende } \\
\text { Flores, } \\
\text { SMAK Santo } \\
\text { Yoseph } \\
\text { Denpasar. }\end{array}$ \\
\hline 4 & $\begin{array}{l}\text { Minoritas muslim, } \\
\text { Katholik, Hindu, Buddha, } \\
\text { Khonghucu pada sekolah } \\
\text { atau daerah mayoritas } \\
\text { kristen }\end{array}$ & $\begin{array}{l}\text { SMAN } 1 \\
\text { SMK Gloria } \\
\text { Manado, } \\
\text { SMPN 2 Ambon. }\end{array}$ \\
\hline 5 & $\begin{array}{l}\text { Minoritas Kristen, } \\
\text { Katholik, Hindu, Buddha, } \\
\text { Khonghucu pada sekolah } \\
\text { atau daerah mayoritas } \\
\text { muslim }\end{array}$ & $\begin{array}{l}\text { Labschool } \\
\text { Jakarta, dan } \\
\text { SMAN } 1 \text { Kab. } \\
\text { Bogor. }\end{array}$ \\
\hline
\end{tabular}


Informan penelitian terdiri atas tokoh pendidikan, tokoh keagamaan, dan tokoh pemerintahan dan tokoh masyarakat. Tokoh pendidikan terdiri atas para pejabat di lingkungan Kanwil Kementerian Agama dan Dinas pendidikan setempat, pimpinan dan staff sekolah, guru, dan siswa. Tokoh pemerintahan meliputi pimpinan daerah yang memiliki kebijakan khusus atau perhatian khusus terhadap layanan pendidikan agama siswa tanpa diskriminasi di sekolah. Dan tokoh masyarakat terdiri atas pengurus yayasan penyelenggara pendidikan.

Teknik pengumpulan data menggunakan studi dokumen, wawancara dengan pimpinan sekolah, guru agama, dan siswa; diskusi mendalam, triangulasi, dan observasi, snowball. Pengumpulan data pada masing-masing sekolah dilakukan oleh seorang peneliti. Laporan ini fokus menjelaskan tentang layanan pendidikan agama di sekolah sesuai agama siswa dan oleh guru agama yang seagama dengan siswa khususnya kepada siswa beragama yang jumlahnya minoritas.

\section{HASIL DAN PEMBAHASAN}

Secara umum, layanan pendidikan agama pada lokasi penelitian telah diimplementasikan sesuai dengan agama yang dianut oleh siswa. Siswa yang beragama Islam diajar oleh guru yang beragama Islam. Siswa yang beragama Hindu diajar oleh guru yang beragama Hindu. Siswa yang beragama Buddha diajar oleh guru yang beragama Buddha. Siswa yang beragama Kristen diajar oleh guru yang beragama Kristen. Dan demikian pula dengan siswa yang beragama Katholik diajar oleh guru agama Katholik.
Penyelenggaraan pendidikan agama Islam kepada siswa-siswi muslim di kota Denpasar, Manado, Ende, Bangka Belitung pada sekolah yang menjadi lokus penelitian termasuk SMA Ananda Bekasi, dimana warga sekolah yang beragama Islam terbilang kecil, ditemukan praktek pendidikan agama Islam yang baik dan berlangsung di bawah binaan dan asuhan guru agama Islam. Guru agama Islam pada sekolah memiliki otoritas untuk menentukan materi, metode, teknik mengajar, bahkan kegiatan ekstrakurikuler keagamaan dipandu dan dipimpin oleh guru agama Islam. Guru tersebut ada yang berstatus sebagai aparatur sipil negara, dan ada yang bersifat swasta atau guru yayasan. Beberapa sekolah di lokasi penelitian belum atau tidak menyediakan masjid untuk menjadi tempat beribadah. Sebagai gantinya, sekolah menyediakan ruangan atau aula di salah satu kelas atau perpustakaan, atau laboratorium untuk digunakan sebagai tempat sholat siswa muslim. Meskipun demikian, ada beberapa sekolah yang memiliki masjid / mushollah, yakni di SMK Bakti Pangkalpinang, Provinsi Bangkabelitung. Demikian pula halnya terkait dengan busana muslim (jilbab), siswa muslim bebas menggunakannya di sekolah pada jam sekolah. beberapa sekolah lokasi peneltian yang tidak ditemukan pakaian jilbab adalah di SMANSA dan SLUA Denpasar. Meski tidak ada larangan tertulis yang dikeluarkan oleh sekolah, tetapi siswi muslim belum merasa bebas/nyaman menggunakan busana muslimah. Siswasiswi muslim juga bebas melaksanakan kegiatan kesiswaan yang berciri khas agama Islam, seperti pengajian, buka puasa bersama, perayaan idul fitri dan hari besar Islam. Pihak sekolah memberikan dukungan 
untuk kelancaran dan kesuksesan acara tersebut.

Pelaksanaan pelajaran pendidikan agama Katholik pada sekolah di lokasi penelitian (Jakarta, Denpasar, Bogor, Bangka-Belitung, Ambon dan Manado) diajarkan oleh guru/tenaga pendidik yang beragama Katholik, baik berstatus sebagai pegawai negeri sipil, atau berstatus honorer (guru tidak tetap yayasan). Ada kasus, dimana sekolah (SMP Labschool) tetap menyediakan guru agama Katholik meskipn tidak ada siswa yang beragama Katholik, dan ada pula kasus di SMAN 1 kabupaten Bogor dimana guru agama Katholik dipegang oleh guru/tenaga pendidik Kristen. Beberapa alat peraga dan tempat pembelajaran agama Katholik dipakai bersama untuk aktivitas pembelajaran pendidikan agama Kristen. Di bawah kendali guru agama Katholik, seluruh aktivitas pembelajaran agama untuk siswa Katholik di sekolah tersebut dilaksanakan, baik di dalam kelas, luar kelas atuupun ekstrakurikuler. Penyediaan buku dan kepustakaan, serta media pembelajaran hingga evaluasi dan penentuan nilai rapor siswa. Aktivitas pembelajaran agama di sekolah dilakukan di ruang kebaktian, atau kelas, dan pada jam setelah jam belajar normal.

Pelaksanaan pelajaran pendidikan agama Kristen pada sekolah dimana siswanya minoritas yakni: Sekolah Menengah Atas (SMA) di Jakarta, Denpasar, Bogor, Bangka-Belitung, Ende, Singkawang, layanan pendidikan agama untuk siswa Kristen juga diasuh oleh guru agama Kristen baik dengan status Pegawai Negeri Sipil (PNS) ataupun status guru honorer yang dibayar oleh sekolah atau yayasan. Secara penuh, guru agama Kristen berwenang mengembangkan metode, pendekatan dan strategi pembelajaran, hingga evaluasi hasil belajar siswa untuk diisi dalam buku raport. Guru agama Kristen diberikan untuk mengajukan pengadaan buku dan fasilitas pembelajaran, menentukan tempat dan waktu pembelajaran. Pada umumnya di lokasi penelitian, pembelajaran agama Kristen di laksanakan di kelas (ruang tertentu), perpustakaan, dan ruang kebaktian. Waktu belajar dilaksanakan di luar jam belajar normal, yakni setelah jam efektif selesai. Ini disebabkan karena siswa dari beberapa kelas (rombongan belajar) harus mengikuti jam belajar efektif secara terpisah, lalu berkumpul di satu ruang kelas yang ditentukan untuk mengikuti pelajaran agama. Kegiatan pendukung pelajaran agama dan ekstrakurikuler yang dijalankan oleh siswa bersama guru adalah perayaan natal, paskah, pembentukan tim koor lagulagu gereja.

Pelayanan pendidikan agamaHindu pada sekolah dimana siswanya berjumlah sedikit, yakni pada Sekolah Menengah Atas (SMA) Labschool Jakarta, Bogor, Ende, Manado, Pangkalpinang, layanan pendidikan agama untuk siswa yang beragama Hindu dipegang oleh guru/tenaga pendidik yang beragama Hindu berstatus honorer, atau bekerjasama dengan lembaga keagamaan, yakni Pura dengan menempatkan seorang Pandite untuk mengajarkan pelajaran HIndu. Guru agama Hindu bekerjasama dengan sekolah dalam memenuhi ketersediaan buku pelajaran. Siswa dan gurunya mendapatkan kesempatan untuk melaksanakan aktivitas bakti sosial dan merayakan hari besar agama Hindu. Di SMAN 1 Manado, misalnya, siswa dan guru yang beragama Hindu secara rutin menyelenggarakan upacara Saraswati, 
Galungan, Kuningan, Nyepi, Simaratri, Purnama, dan Tilem.

Demikian pula halnya dengan layanan pendidikan agama Buddha pada sekolah dimana siswanya berjumlah sedikit, yakni pada Sekolah Menengah Atas (SMA) di kota Denpasar, pelayanan pendidikan agama Buddha dilaksanakan oleh guru agama Buddha berstatus honorer yang digaji oleh sekolah dan yayasan. Di SMAN 1 Denpasar, untuk melayani 35 orang siswa yang beragama Buddha, sekolah menyiapkan seorang guru agama Buddha yang berasal (digaji oleh sekolah) dari guru agama Buddha SMAN 8 Denpasar. Sementara untuk kasus di SMA Yayasan Saraswati Denpasar, guru pendidikan agama Buddha di angkat oleh yayasan sebanyak satu orang untuk melayani 6 orang siswa Buddha.

Penjelasan di atas menunjukkan adanya contoh yang dapat menjadi rujukan dalam penyelenggaraan pendidikan agama di sekolah meskipun terdapat berbagai agama yang berbeda-beda. Ada sekolah yang mayoritas warga dan siswanya muslim, dapat menjadi contoh dalam praktek (best practice) menyediakan layanan pendidikan agama kepada siswa yang minoritas beragama Katholik, Kristen, Hindu, dan Buddha. Di SMA Labschool Jakarta, meskipun terdapat populasi peserta didik yang mayoritas Muslim, tetapi peserta didik yang beragama Kristen, Katholik, dan Hindu mendapatkan layanan dari guru agama yang sesuai dengan agama siswa. Ada sekolah yang mayoritas warga dan siswanya beragama Katholik, yakni SMAK Santo Yoseph dan SMPN Ende Flores, dapat menjadi contoh bagi praktek (best practice) layanan pendidikan agama kepada siswa yang minoritas beragama Islam, Kristen, Hindu, Buddha dan Konghucu. Ada sekolah yang mayoritas warga dan siswanya beragama Kristen, yakni SMAN 1 Manado, dan SMK Gloria Manado, dapat menjadi contoh bagi praktek (best practice) layanan pendidikan agama kepada siswa yang minoritas beragama Islam, Katholik, Hindu, Buddha. Ada sekolah dan daerah yang mayoritas warga dan siswanya beragama Hindu, yakni SMAN 1 Denpasar dan SLTA Saraswati Denpasar, dapat menjadi contoh bagi praktek (best practice) layanan pendidikan agama kepada siswa yang minoritas beragama Islam, Kristen, Katholik, Buddha. Ada sekolah yang mayoritas warga dan siswanya beragama Buddha, yakni SMA Ananda Bekasi, SMK Pangkalpinang, dan SMK Singkawang, dapat menjadi contoh bagi praktek (best practice) layanan pendidikan agama kepada siswa yang minoritas beragama Islam, Katholik, Kristen, dan Hindu. Khusus untuk contoh bagi praktek (best practice) layanan pendidikan agama kepada siswa yang minoritas beragama Khonghucu, dapat ditemukan di SMA Katholik Santo Joseph Denpasar. Di sekolah ini, meskipun hanya terdapat 5 orang siswa Khonghucu, sekolah bekerjasama dengan yayasan tetap menyediakan seorang guru agama Khonghucu.

Dalam hal ketersediaan guru agama, layanan pendidikan agama pada tiap sekolah tersebut disampaikan dalam bentuk matriks, seperti di bawah ini. 
Tabel 2: Matriks ketersediaan guru Agama dan siswa di sekolah lokus penelitian.

\begin{tabular}{|c|c|c|c|c|c|c|c|}
\hline \multirow{2}{*}{ No. } & \multirow{2}{*}{ NAMA SEKOLAH } & \multicolumn{6}{|c|}{ LAYANAN PENDIDIKAN AGAMA } \\
\hline & & Islam & Katholik & Kristen & Hindu & Buddha & K.tcu \\
\hline 1 & SMA Labschool Jkrt & $2 / 741$ & $1 / 1$ & $1 / 9$ & $1 / 6$ & - & - \\
\hline 2 & SMAN 1 Kab. Bogor & $3 / 948$ & $2 / 122$ & & $0 / 2$ & - & - \\
\hline 3 & SMPN 2 Ambon & $5 / 1.436$ & $1 / 14$ & $6 / 146$ & & & \\
\hline 4 & SMAN 1 Manodo & $1 / 297$ & $1 / 73$ & $4 / 1440$ & $1 / 7$ & & \\
\hline 5 & SMK Manado & $1 / 54$ & $1 / 28$ & $2 / 285$ & - & - & - \\
\hline 6 & SMPN Ende Flores & $2 / 243$ & $2 / 317$ & $1 / 74$ & - & - & - \\
\hline 7 & SMK Singkawang & $2 / 460$ & $1 / 38$ & $1 / 115$ & - & $2 / 316$ & \\
\hline 8 & SMAN 1 Denpasar & $1 / 78$ & $1 / 30$ & $1 / 29$ & $4 / 1135$ & $1 / 35$ & - \\
\hline 9 & SLUA Denpasar & $1 / 134$ & & $1 / 35$ & $4 / 703$ & $1 / 6$ & \\
\hline 10 & SMAK SanJosep & $1 / 114$ & $2 / 276$ & $1 / 263$ & $2 / 333$ & $1 / 143$ & $1 / 5$ \\
\hline 11 & SMA Ananda Bekasi & $1 / 47$ & $1 / 42$ & $1 / 145$ & $1 / 9$ & $2 / 128$ & \\
\hline 12 & SMK Bakti Pangkal Pinang & $2 / 76$ & $3 / 103$ & $3 / 114$ & $0 / 1$ & $3 / 233$ & $0 / 130$ \\
\hline
\end{tabular}

Secaraumum, matrik diatas menjelaskan ketersediaan guru agama yang melayani pengajaran pendidikan agama di sekolah. Sebagai contoh pada nomor satu, di SMA Labschool Jakarta, terdapat 741 orang siswa yang beragama Islam di layani oleh 2 orang guru agama Islam; 1 orang siswa beragama Katholik dilayani oleh 1 orang guru agama Katholik; 9 orang siswa beragama Kristen dilayani oleh 1 orang guru beragama Kristen; 6 orang siswa beragama Hindu dilayani oleh 1 orang guru agama Hindu. Berdasarkan uraian tersebut di atas, beberapa hal penting untuk dianalisis adalah tentang keberadaan guru agama, kurikulum, alokasi waktu dan tempat pengajaran agama di sekolah, serta sarana prasarana pembelajarana agama bagi siswa minoritas.

Dari berbagai kasus yang terdapat di lokasi penelitian, terdapat 3 (tiga) pola penyediaan guru agama di sekolah untuk melayani pendidikan agama sesuai agama siswa, yakni: oleh pemerintah atau pemerintah daerah, oleh sekolah, yayasan dan lembaga keagamaan. Penyediaan guru agama oleh pemerintah dilaksanakan sesuai aturan rekruitmen pegawai negeri sipil (PNS). Penyediaan guru agama oleh sekolah, biasanya dilakukan untuk menutupi kekosongan guru agama yang diangkat oleh pemerintah. Artinya, dalam kasus pemerintah cq. Kementerian agama atau Pemerintah daerah setempat tidak menempatkan guru di sekolah tertentu, maka sekolah tersebut mengangkat guru honorer dengan persetujuan komite sekolah. Untuk sekolah swasta di bawah manajemen yayasan, maka kekosongan guru agama menjadi kewenangan yayasan untuk merekrut dan mengangkat guru agama yang dibutuhkan. Dalam kasus pemerintah daerah, sekolah atau yayasan tidak memiliki kemampuan untuk mengadakan guru agama, maka sekolah bekerja sama dengan lembaga keagamaan, menyediakan layanan pendidikan agama kepada siswa di sekolah tersebut. Kasus ini terjadi pada sekolah dengan jumlah siswa yang kurang dari 15 orang.

Secara umum, guru pendidikan agama di sekolah menggunakan kurikulum nasional (KTSP dan / atau Kurtilas) sebagai acuan dan landasan dalam mengembangkan materi pelajaran agama kepada siswanya. 
Sekolah menyediakan buku paket pelajaran agama, baik berasal dari pemerintah (kementerian agama, dinas pendidikan, ataupun melalui anggaran sekolah). Guru agama memiliki kewenangan penuh dalam menentukan sumber belajar, materi pelajaran, membuat perencanaan mengajar, merancang aktivitas pembelajaran hingga menentukan nilai raport mata pelajaran pendidikan agama (evaluasi). Pada beberapa sekolah lokasi penelitian, ditemukan jumlah kepustakaan pendidikan agama dalam jumlah yang terbatas, khususnya untuk agama dengan jumlah penganut siswa minim. Selain melalui pendekatan intrakurikuler, penanaman, pembentukan pengetahuan dan keterampilan beragama dilakukan melalui kegiatan ekstrakurikuler. Kegiatan ekstrakurikuler keagamaan di sekolah dirancang bersama oleh guru agama dan siswa. Baik pada sekolah yang agama mayoritas, ataupun pada sekolah yang agama minoritas, kegiatan ekstrakurikuler keagamaan bersifat terbuka untuk semua siswa sesuai dengan agama masing-masing. Siswa bebas menentukan jenis dan frekwensi aktivitas sesuai agamanya masing-masing, sepanjang tidak mengganggu jadwal pelajaran dan aktivitas persekolahan.

Proses belajar dan mengajar secara umum dilaksanakan di kelas, luar kelas, dan pada jam pelajaran atau di luar jam pelajaran. Siswa agama tertentu dengan jumlah besar akan melaksanakan pembelajaran di ruang kelas (sekolah) sesuai jadwal pelajaran yang sudah ditentukan.Padajam (pelajaran agama untuk siswa yang jumlah penganutnya besar) tersebut, siswa yang beragama lain dipersilahkan untuk keluar melaksanakan aktivitas sendiri.
Untuk siswa penganut agama tertentu yang berjumlah sedikit, mereka menyesuaikan tempat dan waktu pembelajaran. Tempat pembelajaran dapat menggunakan kelas, perpustakaan, laboratorium atau tempat ibadah. Waktu pembelajaran pada umumnya dilaksanakan di luar jam normal pelajaran. Pada jam normal seluruh siswa dari seluruh agama, mengikuti mata pelajaran umum seperti dijadwal oleh masing-masing kelas.

Pola yang menarik ditemukan di sekolah menengah atas Katholik (SMAK) Santo Yosep Denpasar, yang menjadwalkan mata pelajaran agama pada hari Jum'at untuk kelas 10 dan 11, serta hari Sabtu untuk kelas 12. Pada hari tersebut terjadi moving class (perpindahan ruangkelas) untuk menempati ruang belajar pendidikan agama sesuai agama masing-masing siswa yang diajarkan oleh guru yang seagama dengan siswa. Siswa yang beragama Hindu akan berkumpul sesama siswa Hindu dengan guru agama Hindu pada satu atau beberapa ruang kelas yang tersedia. Demikian pula dengan siswasiswi muslim, Kristen, Katholik, Buddha, dan Khonghucu.

Sarana dan prasarana pembelajaran yang dimiliki oleh sekolah, secara umum dapat juga digunakan untuk pembelajaran pendidikan agama. Ruang kelas, infokus, perpustakaan, semuanya disediakan oleh sekolah atau yayasan untuk seluruh mata pelajaran.Untuk hal-hal yang bersifat spesifik keagamaan, masing masing guru agama diberikan kewenangan untuk mengupayakan pengadaannya bekerjasama dengan pihak komite sekolah atau dengan yayasan. 
Pengadaan dan ketersediaan buku pelajaran, dan alat peraga keagamaan, sangat ditentukan oleh inisiatif, dan kreativitas guru agama, kemampuan sekolah dan kebijaksanaan pimpinan sekeolah atau yayasan. Beberapa sekolah pada lokasi penelitian memiliki buku pelajaran dan peraga keagamaan yang memadai. Namun demikian, ada banyak sekolah yang belum memenuhi standard minimal kepustakaan dan alat peraga keagamaan. Keberadaan, peran dan fungsi pemerintah, pemerintah daerah (kantor kemenag dan dinas pendidikan setempat) untuk memenuhi standar minimal buku kepustakaan agama dan alat peraga keagamaan masih belum efektif dan maksimal.

Secara umum pengurus yayasan, lembaga keagamaan, komite sekolah, dan pimpinan sekolah pada wilayah yang diteliti menyatakan persetujuan terhadap layanan pendidikan agama oleh guru agama sesuai agama siswa. Mereka secara sadar mengakui adanya ketentuan undang-undang dan kebijakan pemerintah tentang layanan pendidikan agama kepada peserta didik dan sudah mengimplementasikannya sejak undang-undang sisdiknas nomor 20 tahun 2003 diundangkan. Mereka secara sadar memposisikan mata pelajaran pendidikan agama di sekolah masing-masing sebagai dasar pembentukan moral, karakter, dan kepribadian anak. Selain melalui pembelajaran agama di kelas, pembentukan moral, karakter, dan kepribadian anak di sekolah juga didukung melalui keteladanan pada guru dan staf sekolah. Dengan dasar berpikir tersebut maka posisi pendidikan agama di sekolah sangat kuat.

Keberadaan pimpinan sekolah, komite sekolah, dan yayasan yang menaungi sekolah menjadi salah satu faktor pendukung utama bagi terselenggaranya layanan pendidikan agama sesuai agama siswa di sekolah. Tantangan dan hambatannya ada pada kesadaran, pemahaman dan kemampuan finansial untuk mengangkat dan memenuhi ketersediaan guru agama di sekolah.

\section{PENUTUP}

Dari uraian di atas, maka dapat disimpulkan bentuk layanan pendidikan agama kepada siswa beragama minoritas terselenggara dengan berbagai bentuk yang sesuai dengan karakteristik dan status sekolah. Pada sekolah yang menjadi lokasi penelitianiniterlihatadanyaprakteklayanan (best practice) yang dapat dijadikan model, yakni pada SMA Labschool Jakarta, SMA Ananda Bekasi, SMA Katholik Santo Josep Denpasar, SMAN 1 Manado, SMPN 2 Ende Flores, SMPN 2 Ambon, dan SMK Singkawang. Layanan pendidikan agama sesuai agama siswa dilakukan oleh guru agama yang seagama dengan siswa, sebagaimana amanat sistem pendidikan nasional dalam undang-undang nomor 20 tahun 2003 pasal 12, ayat, 1 point a. Di sekolah yang menjadi best practice tersebut, para guru agama yang mengelolah dan mengendalikan layanan pendidikan agama kepada siswa diberikan tanggungjawab oleh pimpinan sekolah dan komite sekolah atau yayasan untuk menyelengggarakan pendidikan agama baik dalam bentuk intrakurikuler ataupun dalam bentuk ekstrakurikuler. Para guru agama juga menjadi pembina bagi aktivitas ekstrakurikuler keagamaan seperti peringatan hari besar umat beragama, dalam bentuk kerja sama dengan pengurus OSIS bidang kerohanian. Salah satu faktor 
utama yang mendukung terlaksananya layanan pendidikan agama sesuai agama siswa oleh guru yang seagama dengan siswa, adalah faktor kepemimpinan, inisiatif, dan kesadaran pimpinan sekolah, komite sekolah dan yayasan.

Sejalan dengan kesimpulan tersebut, maka kasus-kasus dimana ada sekolah yang tidak bersedia memberikan layanan pendidikan agama sesuai agama siswa, dan membatasi kebebasan siswa dalam mengekspresikan iman dan kepercayaannya di lingkungan sekolah harus dikaji lebih lanjut, terutama bagi pemerintah daerah yang di wilayahnya terdapat praktek diskriminasi atau pemaksaan dan pengurangan hak anak dalam memperoleh layanan pendidikan agama di sekolah sesuai undang-undang sistem pendidikan nasional. Riset ini menemukan fakta bahwa semua sekolah pada lokus penelitian (Islam, Katholik, Kristen, Hinddu, Buddha, dan Konghutcu) dapat menyediakan layanan pendidikan agama sesuai agama yang dianut oleh siswa. Tidak ada paksaan bagi siswa untuk mengikuti pelajaran agama tertentu yang ditetapkan oleh sekolah. Untuk meningkatkan praktek layanan pendidikan agama sesuai agama siswa di sekolah, maka upaya persuasif dan proaktif harus dilakukan antara lain memenuhi jumlah guru pendidikan agama di sekolah.

\section{UCAPAN TERIMA KASIH}

Atas selesainya karya tulis ini, saya menghaturkan terima kasih kepada Kepala Puslitbang Pendidikan Agama dan Keagamaan Balitbang \& Diklat Kemenag RI, yang telah memberikan kesempatan, dan dukungan untuk melaksanakan dan menjadi kordinator dari penelitian Layanan pendidikan agama sesuai agama siswa di sekolah. Kepada teman-teman Peneliti di lingkungan Puslitbang Penda juga tidak lupa saya haturkan terima kasih atas kerja kerasnya melakukan riset pada berbagai wilayah dan menyampaikan laporan.

\section{DAFTAR PUSTAKA}

Baum, Sandy. (2011): and McPhaursen, Michael. 2011. Is Education A Public Good or A Private Good. http://chronicle. com/blogs/innovations/is-educationa-public-good-or-a-private-good/28329

Colbran, Nicola. (2007): Hak Kebebasan Beragama atau Berkepercayaan, Makalah Workshop Memperkuat Justisiabilitas Hak-hak Ekonomi, Sosial, dan Budaya: Prospek dan Tantangan, Yogyakarta.

Hilda Taba, Current conception of the Function of The School. http://faculty.fordham. edu/kpking/classes/uege5102-presand-newmedia/Hilda\%20 Taba-\%20 Function\%20of\%20the\%20School.pdf

Mudzhar, Atho. (2010): Pengaturan Kebebasan Beragama dan Penodaan Agama di Indonesia dan Berbagai Negara, makalah pada Kajian tentang Putusan Mahkamah Konstitusi No. 140 tanggal 19 April 2010, tentang Uji Materil UU No. 1/PNPS/1965.

Poloni, Lori. (2013): Education: A Public or Privat Goods. http://nau.edu/PPI/_ Forms/Education-A-Public-or-PrivateGood/

Puslitbang Pendidikan Agama dan Keagamaan. (2014): Laporan Tahunan Pendidikan Agama dan Keagamaan di Indonesia tahun 2013, Jakarta. 
Smith, Noah. 2011. Is Education A Public Good?. http://noahpinionblog.blogspot. com/2011/06/is-education-publicgood.html.

Stewart Riddle. (2011): Education is a public good, not a private commodity, http:// theconversation.com/educationis-a-public-good-not-a-privatecommodity-31408.

Tholkhah, Imam. (2013): Pendidikan Toleransi Keagamaan: Studi Kasus SMA Muhammadiyah Kupan Nusa Tenggara Timur, Jurnal Edukasi Vol. 11, nomor 2.

\section{Referensi Peraturan:}

Peraturan Pemerintah Nomor 55 Tahun 2007, tentang Pendidikan Agama dan Keagamaan.

Undang Undang Republik Indonesia nomor 39 tahun 1999, tentang Hak Asasi Manusia.

Undang-Undang Republik Indonesia nomor 20 tahun 2003 tentang Sistem Pendidikan Nasional.

Undang-Undang Republik Indonesia nomor 23 tahun 2002 tentang Perlindungan Anak.

UUD 1945, Amandemen Ke-2.

\section{Referensi Internet:}

http://kbbi.web.id/sekolah, dikutip, tanggal 9 April 2015.

http://sosbud.kompasiana. com/2013/07/12/menjadi-minoritasdi-sekolah-negeri-576236.html, dikutip pada tanggal: 15 Januari 2015.

http://www.sesawi.net/2012/08/14/meskisiswa-muslim-minim-sd-karangturisemarang-gelar-kegiatan-ramadhan/, dikutip pada tanggal 13 Januari 2015. http://www.solopos.com/2015/01/04/ sekolah-intoleran-masih-muncul-diindonesia-564975, dikutip pada tanggal: 13 Januari 2015.

\section{Referensi Temuan Lapangan:}

Annahidl, Nunu Ahmad, (2015): Laporan Penelitian Layanan Pendidikan Agama di SMAN 1 Manado.

Basri, Husen Hasan, (2015): Laporan Penelitian Layanan Pendidikan Agama di SMK Manado.

Faiqoh, (2015: Laporan Penelitian Layanan Pendidikan Agama di SMA Ananda Bekasi.

Hayadin, (2015): Laporan Penelitian Layanan Pendidikan Agama di SMAN 1 Denpasar.

Mastiyah, Iyoh., (2015): Laporan Penelitian Layanan Pendidikan Agama di SMAN 1 Bogor.

Muin Abdul, (2015): Laporan Penelitian Layanan Pendidikan Agama di SLUA Denpasar.

Munawiroh, (2015): Laporan Penelitian Layanan Pendidikan Agama di SMA Labschool Jakarta.

Murtadho, (2015): Laporan Penelitian Layanan Pendidikan Agama di SMA Ende.

Qowaid, (2015): Laporan Penelitian Layanan Pendidikan Agama di SMK Bakti Pangkalpinang.

Ta'rif, (2015): Laporan Penelitian Layanan Pendidikan Agama di SMPN 1 Ambon. 